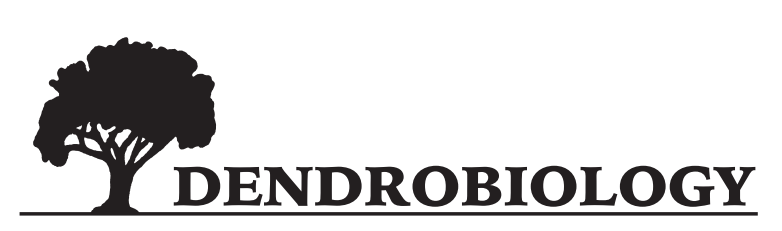

2015, vol. 73, 175-181

http://dx.doi.org/10.12657/denbio.073.018

\author{
Ovidiu Badea, Ion Dumitru, Cristian Cojocia, Ionel Popa
}

\title{
The radial growth-competition relationship in Picea abies stands affected by windfall
}

Received: 20 June 2014; Accepted: 26 January 2015

\begin{abstract}
Actual status of mountain forests especialy, of Norway spruce (Picea abies Karst. (L)) stands is a result of combined action between forest management measures and biotic and abiotic risk factors. In this context, tree growth dynamics is a result of multifactor interaction (competition, disturbance, management practice, climate etc.). Wind damage affect the stand structure and normal ecosystem functions including the relationship between individual tree growth and competition processes. Though, it is recorded a diminishing of productive capacity for affected stands as well as a significant diameter increment for remaining standing trees. The correlation between tree growth (cumulate basal area increment in the last 10 years) and competition (Hegyi and Schutz competition indices) was analysed in stands with different windfall intensity. No relationship between tree growth and competition was observed in highly affected stands. Schutz competition index explains better individual tree growth comparing with Hegyi index in low or no-affected stand by windthrow. The variability of the basal area increment $\left(\ln \Delta g_{10}\right)$, explained by competition indices, is rather low $(<2 \%)$ in the stand that had been highly affected by windfall, regardless of the selected competition index. Thus, significant reduction of the stand density related to number of trees (low density), as a consequence of high intensity windfalls, crown competition has a very small influence on the basal area increment comparing with situations met in low (high density) and moderate (medium density) affected stands.
\end{abstract}

Additional key words: Norway spruce stand, competition index, basal area increment, windfalls risk factors

Addresses: O. Badea, I. Popa (corresponding author) - Forest Research and Management Institute, 128 Bld. Erorilor, Voluntari, Romania, e-mail: popaicas@gmail.com

I. Dumitru - Valahia University, 2, Bld. Carol I, Târgoviște, Romania

C. Cojocia - Transilvania University, 1, Sirul Beethoven, Brasov, Romania

\section{Introduction}

In terms of structure and functional relationships, the dynamics of mountain forest ecosystems is the product of specific internal processes, correlated with the enforcement of forest management measures and with the effects of the biotic and abiotic risk factors (Castagneri et al. 2008). The specific competitive processes in forest ecosystems have a significant influence on both the diameter and height growth. Growth processes are high correlated with light conditions. Crown shape and morphology is influenced by the availability of light. Light condition depends on topographic factors and local competition between trees (Lang et al. 2010).

Tree growth depends on the size, shape and functioning of the foliar system, i.e. of the crown parameters. The size and shape of the crown is a direct result 
of the interaction between neighbouring trees. The dynamics of radial, height, basal area or volume increment is directly related to the inter-tree and inter- specific competition. Competition is a result of negative interaction between trees for aboveground (e.g. light) or belowground resources (e.g. water) (Larocque et al. 2013). The competition for resources between neighbouring individuals is one of the main predictors of tree growth (Tome and Burkhart 1989). The effects of the competition on the individual trees growth has been the subject of numerous research studies, while the competition indices were included in various increment models (e.g. Pretzsch et al. 2002).

Wind is an importance disturbance factor in mountain ecosystems, and manly in Norway spruce artificial monoculture (Panayotov et al. 2011). The impact of a windthrow is reflected in the significant changes occurring in the structure of the stands, through a systematic stand density reduction process (Popa 2007). Reduction of stand density, by human intervention (e.g. thinning) or disturbance factors (e.g. wind, insects) induce an increase of light availability and reduce competition for nutrients and water (Larocque et al. 2013). The occurrence of gaps or the relatively even reduction of stand density influences the intra- or inter-specific competition, with direct effects on the growth processes (Aakala et al. 2013).

The main objective of the study is to measure the statistical relationship between the competition indices and the trees growth in Norway spruce (Picea abies Karst. (L)) stands affected by windfall of different intensity. Our hypothesis is that a decrease of stand density due to wind damage will reduce the influence of competition on tree growth.

\section{Materials and methods}

The research has been conducted in the north of the Eastern Romanian Carpathians in two artificial Norway spruce stands aged 65 (plot $43 \mathrm{H}$ ) and 80 years (plot 48A). In 2002 the study region was affected by a high intensity wind damage been felled over 400.000 $\mathrm{m}^{3}$ in an area of 7000 ha (Popa 2008). According with local topography the wind damage intensity varies between 10 to $100 \%$ of stoking volume. Two 0.5 ha permanent plots have been established in each stand, with different stand density levels, induced by windfall. The wind damage intensity was established comparing actual number of tress per ha (after removal of felled trees by wind) with normal number of trees per ha according with yield tables (function of specie, age and stand index) (Table 1).

All living trees have been subject to dendrometric measurements such as species, diameter at breast height DBH $(\mathrm{cm})$, tree height $(\mathrm{m})$, length of the crown (m), two crown diameters $(\mathrm{m})$ (along and perpendicular to the slope) and $\mathrm{x}$ and $\mathrm{y}$ coordinates $(\mathrm{m})$. A radial increment core from the $1.3 \mathrm{~m}$ height has been extracted from each tree. The increment samples have been processed, measured and checked according to classical dendrochronological procedures (Cook and Kairiukstis 1990).

The quantification of the basal area increment has been conducted starting the measurements from the cambium rather than from the pith (Huang et al. 2013). The DBH was converted into diameter at breast height without bark $\left(\mathrm{DBH}_{\mathrm{c}}\right)$ according to the equation suggested by Giurgiu et al. (2004) for Norway spruce.

$D B H_{c}=D B H-\left(0.278+0.0398 \times D H B-0.000156 \times D B H^{2}\right)$

The cumulate basal area increment for the past 10 years $\left(\Delta \mathrm{g}_{10}\right)$ has been derived from the radial increment data set.

$$
\Delta g_{10}=\pi\left(D B H_{c}-i r_{10}\right) \times i r_{10}
$$

where $i r_{10}$ represents the cumulated radial increment within the past 10 years period.

In order to identify the relationship between competition and tree growth, we have selected two individual based competition indices, distance dependent, as follows: the Hegyi index (Mailly et al. 2003) and the Schütz competition index (Ung et al. 1997).

Table 1. Summary statistics for Norway spruce plots

\begin{tabular}{|c|c|c|c|c|}
\hline Variable & $43 \mathrm{H} 1$ & $43 \mathrm{H} 2$ & $48 \mathrm{~A} 1$ & $48 \mathrm{~A} 2$ \\
\hline Trees per ha & 268 & 452 & 294 & 392 \\
\hline Basal area $\left(\mathrm{m}^{2} \times \mathrm{ha}^{-1}\right)$ & 28.6 & 35.8 & 38.2 & 42.1 \\
\hline Volume $\left(\mathrm{m}^{3} \times \mathrm{ha}^{-1}\right)$ & 413.9 & 550.4 & 662.1 & 719.6 \\
\hline Age (years) & 65 & 65 & 80 & 80 \\
\hline Mean DBH $(\mathrm{cm})$ & 40.1 & 36.9 & 44.2 & 40.5 \\
\hline Mean h (m) & 34.1 & 33.2 & 39.7 & 36.5 \\
\hline Mean individual tree basal area increment $\Delta g_{10}\left(\mathrm{~cm}^{2}\right)$ & 189.5 & 139.9 & 159.5 & 167.6 \\
\hline Normal trees per ha* & 887 & 887 & 549 & 549 \\
\hline Stand density & 0,30 & 0,51 & 0,54 & 0,72 \\
\hline Wind damage level & High & Moderate & Moderate & Low \\
\hline
\end{tabular}

number of trees per ha from yield table at stand density equal with 1 
The Hegyi index is based on the ratio between the $\mathrm{DBH}$ of the competing tree and the one of the subject tree, weighed by the distance between them. Hegyi index is recommended as a very good predictor for basal area increment and is widely used in competition studies (Contreras et al. 2011). The selection of the competitor trees has been conducted depending on the influence area, i.e. from a circle with a radius that equals one third of the height of the subject tree (Mailly et al. 2003).

$$
\mathrm{ICH}_{i}=\sum_{j=1}^{N} \frac{d_{j}}{d_{i}} \cdot \frac{1}{L_{i j}}
$$

where: ICH - the Hegyi competition index; $d_{i}-$ DBH of the subject tree; $d_{j}-$ DBH of the competitor tree; $\mathrm{L}_{\mathrm{ij}}$ - the distance between the subject and the competitor tree.

To include the crowding effect we chose the Schütz competition index (Ung et al. 1997) with two components: a horizontal one, defined by the closeness between the crowns of the two trees under analysis and a vertical one, depending on the height difference. Mathematically speaking, this competition index is measured by means of the formula:

$$
I C S_{i}=\sum_{\substack{j=1 \\ j \neq i}}^{n} 0.65 \frac{h_{j}-h_{i}}{r_{i}+r_{j}}+0.5-\left[\frac{E_{i j}}{r_{i}+r_{j}}\right]
$$
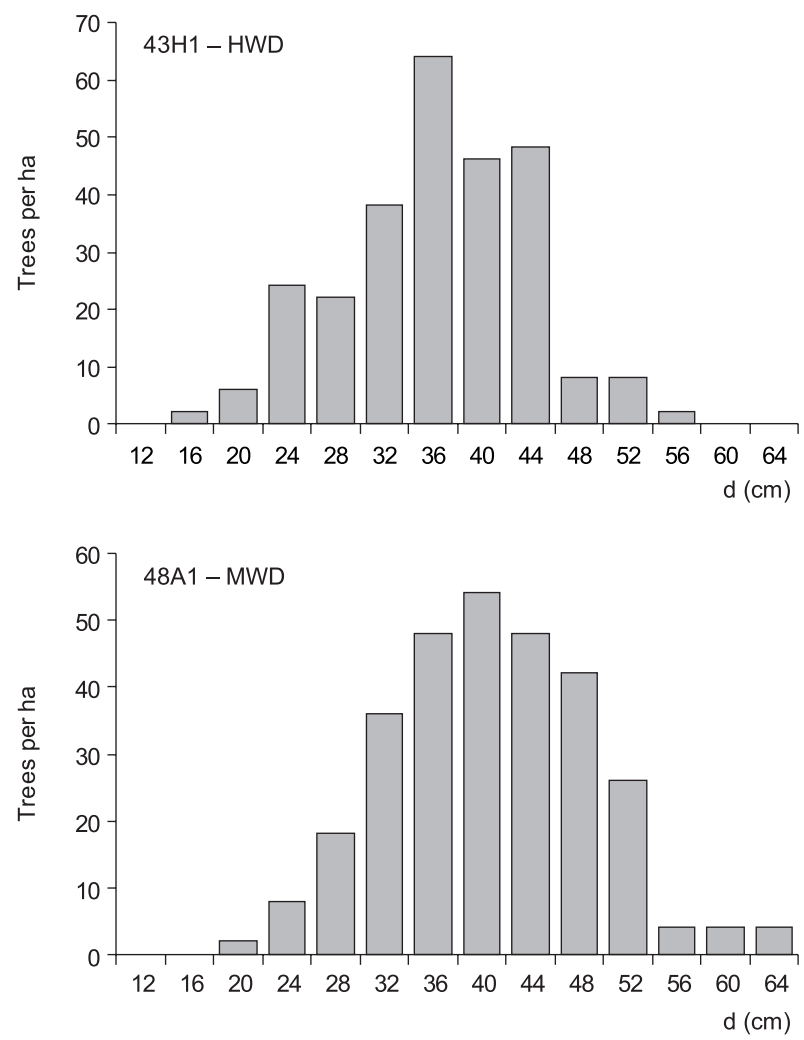

where: ICS - the Schütz competition index; $r_{i}-$ radius of crown of the subject tree; $r_{j}$ - radius of crown of the competitor tree; $h_{i}$ - height of the subject tree; $h_{j}$ - height of the competitor tree; $E_{i j}$ - distance between the crown outer edges of the subject and competitor trees.

Schütz competition index has its own criterion for the selection of competitor trees for a given subject tree. Thus, a competitor tree is identified according to the formula:

$$
E_{i j} \leq 0.5\left(r_{i}+r_{j}\right)+0.65\left(h_{j}-h_{i}\right)
$$

The analysis has been conducted for each plot excluding a $5 \mathrm{~m}$ buffer area in order to prevent underestimating the competition for outer edge trees.

Since the basal area increment has asymmetric distribution, we have normalised it by means of a logarithmic conversion. In order to test the effects of the competition on tree growth, we have used the following linear model:

$$
\ln \Delta g_{10}=a+b \times C I
$$

where CI is either the Hegyi or the Schütz competition index.

The performance level of the regressive model has been measured by means of the root mean square error (RMSE) and of the adjusted coefficient of deter-
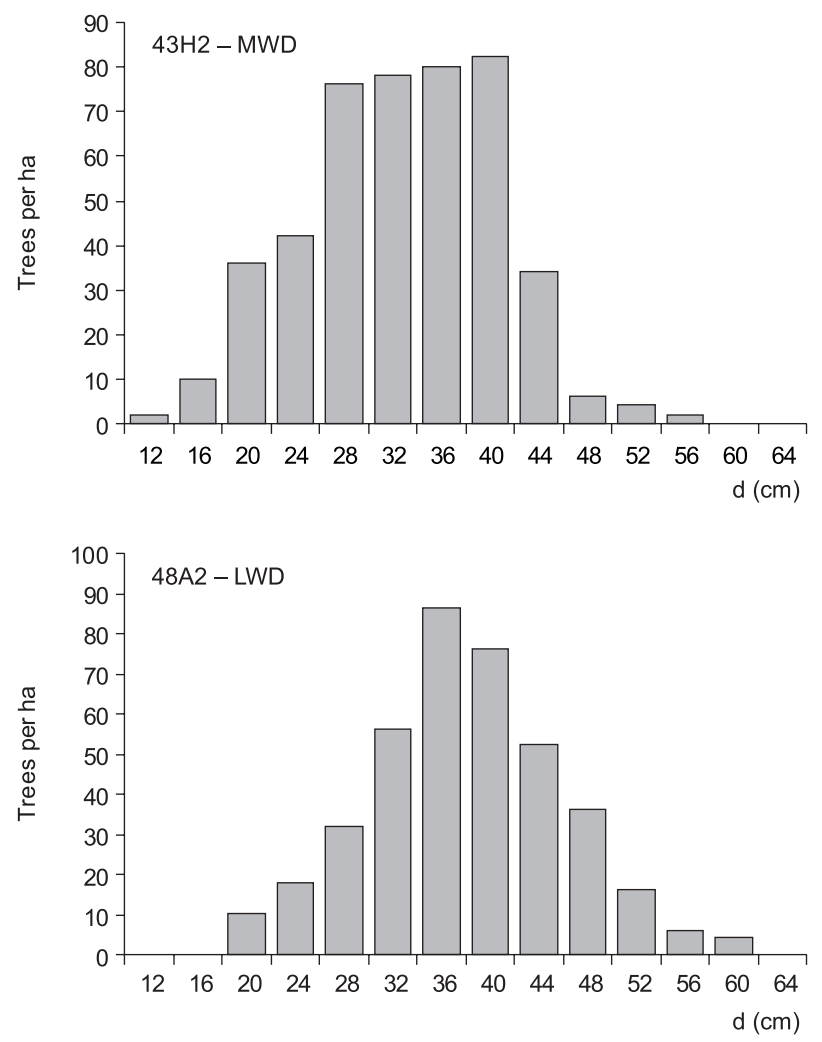

Fig. 1 Distribution of number of trees per diameter classes (LWD - low wind damage intensity, MWD - moderate wind damage intensity, HWD - high wind damage intensity) 
Table 2. Model parameter estimates

\begin{tabular}{|c|c|c|c|c|c|c|}
\hline Plot & $\mathrm{R}^{2}{ }_{\mathrm{ddj}}(\mathrm{RMSE})$ & Variable & Estimate & SE & $\mathrm{t}$ & $\mathrm{P}$ \\
\hline \multirow{4}{*}{$43 \mathrm{H} 1$} & \multirow{2}{*}{$\begin{array}{c}0.017 \\
(0.555)\end{array}$} & Intercept & 4.995 & 0.098 & 50.67 & $<0.0001$ \\
\hline & & ICS & 0.040 & 0.029 & 1.34 & 0.1822 \\
\hline & \multirow{2}{*}{$\begin{array}{c}0.018 \\
(0.580)\end{array}$} & Intercept & 4.920 & 0.145 & 33.73 & $<0.0001$ \\
\hline & & $\mathrm{ICH}$ & 0.104 & 0.075 & 1.37 & 0.1731 \\
\hline \multirow{4}{*}{$43 \mathrm{H} 2$} & \multirow{2}{*}{$\begin{array}{c}0.626 \\
(0.479)\end{array}$} & Intercept & 5.360 & 0.051 & 104.54 & $<0.0001$ \\
\hline & & ICS & -0.166 & 0.009 & -17.44 & $<0.0001$ \\
\hline & \multirow{2}{*}{$\begin{array}{c}0.197 \\
(0.705)\end{array}$} & Intercept & 5.355 & 0.109 & 48.99 & $<0.0001$ \\
\hline & & $\mathrm{ICH}$ & -0.214 & 0.032 & -6.66 & $<0.0001$ \\
\hline \multirow{4}{*}{$48 \mathrm{~A} 1$} & \multirow{2}{*}{$\begin{array}{c}0.519 \\
(0.453)\end{array}$} & Intercept & 5.390 & 0.064 & 84.52 & $<0.0001$ \\
\hline & & ICS & -0.183 & 0.017 & -10.65 & $<0.0001$ \\
\hline & \multirow{2}{*}{$\begin{array}{c}0.280 \\
(0.553)\end{array}$} & Intercept & 5.844 & 0.155 & 37.64 & $<0.0001$ \\
\hline & & $\mathrm{ICH}$ & -0.478 & 0.073 & -6.50 & $<0.0001$ \\
\hline \multirow{4}{*}{$48 \mathrm{~A} 2$} & \multirow{2}{*}{$\begin{array}{c}0.517 \\
(0.511)\end{array}$} & Intercept & 5.483 & 0.062 & 87.15 & $<0.0001$ \\
\hline & & ICS & -0.221 & 0.017 & -12.58 & $<0.0001$ \\
\hline & \multirow{2}{*}{$\begin{array}{c}0.296 \\
(0.616)\end{array}$} & Intercept & 5.949 & 0.142 & 41.94 & $<0.0001$ \\
\hline & & $\mathrm{ICH}$ & -0.483 & 0.060 & -7.98 & $<0.0001$ \\
\hline
\end{tabular}

mination $\mathrm{R}_{\mathrm{adj}}^{2}$. The model parameters were estimated by means of the ordinary least square, using the REG procedure from SAS (SAS 2013).

\section{Results}

The intensity of windfall is reflected in the number of trees per hectare that are still standing (stand density) compared with normal number of trees per hectare according with yield table. Stand density is minimum in the $43 \mathrm{H} 1$ plot and maximum in the $43 \mathrm{H} 2$
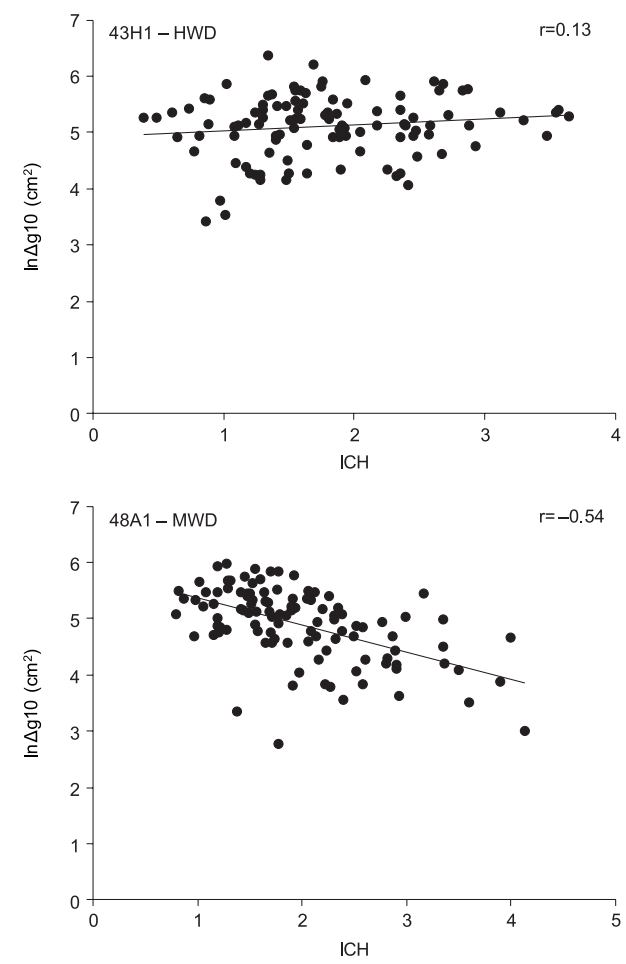

Fig. 2 Relationship between the basal area increment $\left(\ln \Delta g_{10}\right)$ and the Hegyi competition index (LWD - low wind damage intensity, MWD - moderate wind damage intensity, HWD - high wind damage intensity)

plot (Table 1). The stand basal area ranges between $28.6 \mathrm{~m}^{2} \times \mathrm{ha}^{-1}$ and $42.1 \mathrm{~m}^{2} \times \mathrm{ha}^{-1}$. For the stand with high wind damage intensity the number of trees per hectare represent $60 \%$ from moderate affected stand and the basal area $80 \%$.

The diameter distribution is normal in case of low affected stand and asymmetric for stand with high intensity of windthrow (Fig. 1).

The maximum value of competition index of individual trees is higher in the case of the $43 \mathrm{H} 2$ plot $\left(\mathrm{ICS}_{\max }=19.4 ; \mathrm{ICH}_{\max }=10.0\right)$ as compared to the other plots $\left(43 \mathrm{H} 1-\mathrm{ICS}_{\max }=7.8 ; \mathrm{ICH}_{\max }=3.6\right)$. Mean
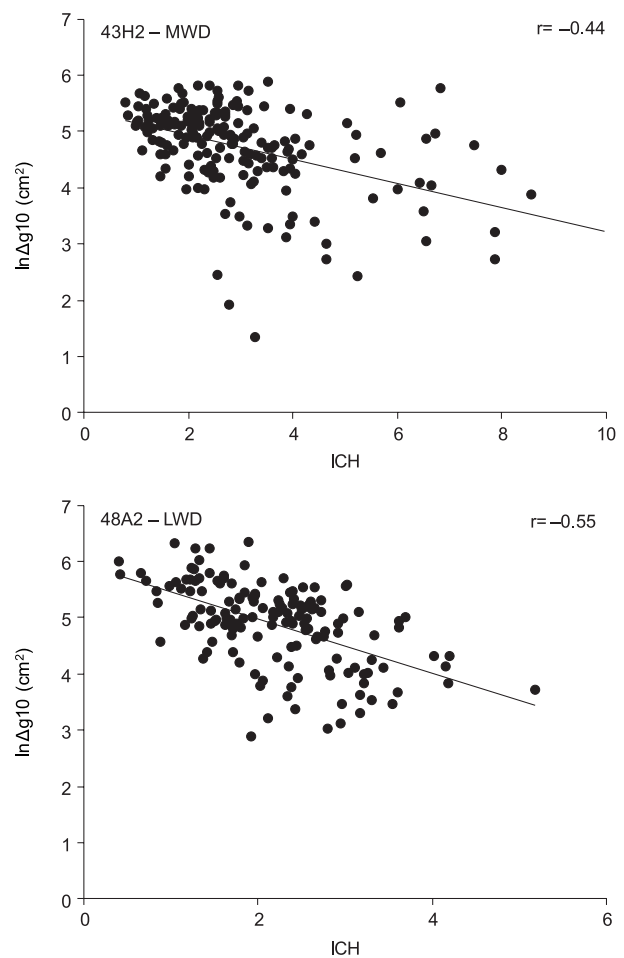

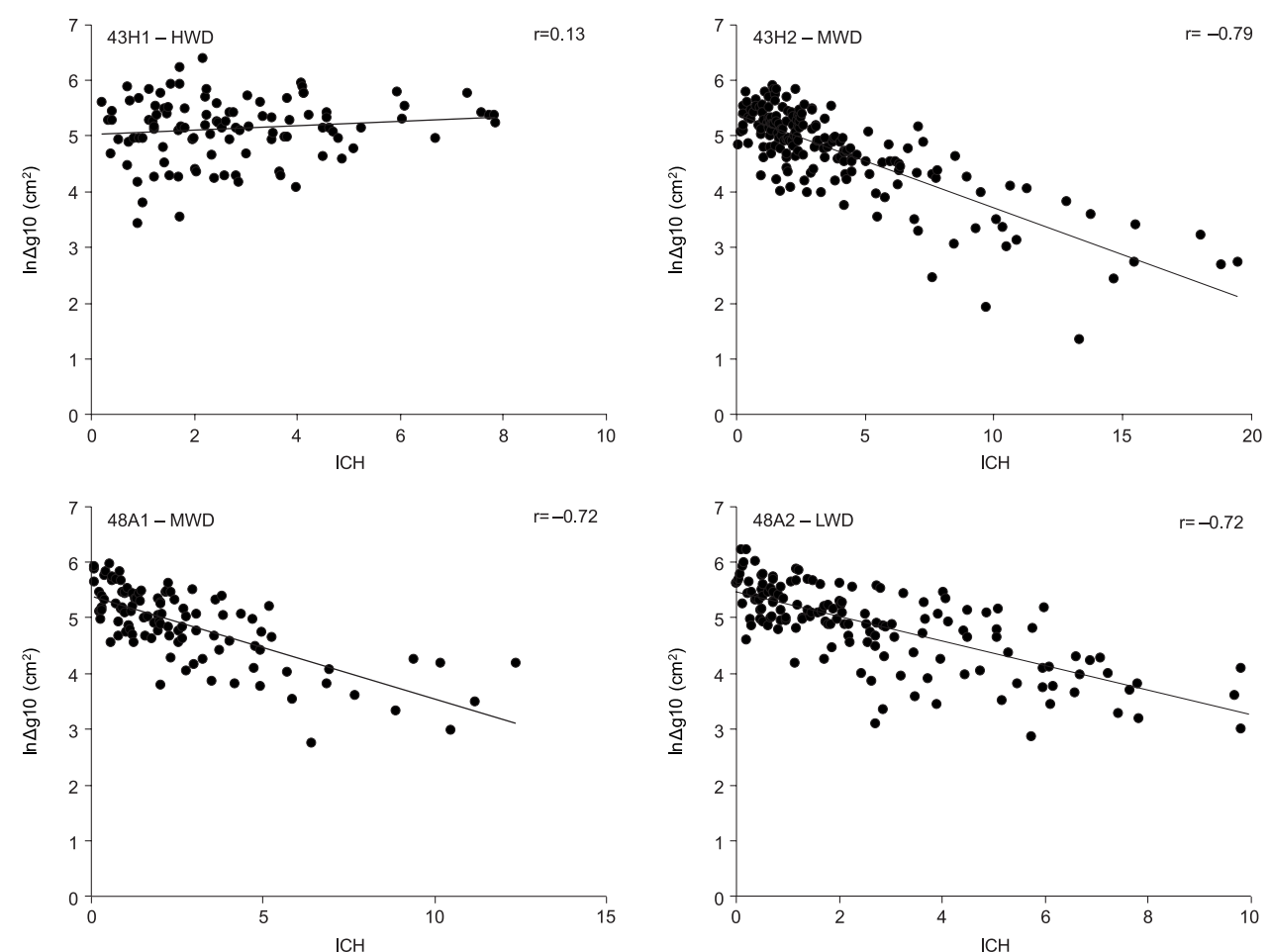

Fig. 3 Relationship between the basal area increment $\left(\ln \Delta g_{10}\right)$ and the Schütz competition index (LWD - low wind damage intensity, MWD - moderate wind damage intensity, HWD - high wind damage intensity)

value of competition index for stand with high and low windthrow intensity are similar, but the standard deviation is $25 \%$ lower in case of highly affected stand.

The correlation coefficient $(r)$ between the basal area increment expressed by means of a logarithmic function $\left(\ln \Delta g_{10}\right)$ and the Hegyi competition index, varies between $r=0.13(p=0.17)$ in the case of the $43 \mathrm{H} 1$ (highly affected by windfall) and $\mathrm{r}=-0.55$ $(\mathrm{p}<0.0001)$ for the 48A2 plot (low windthrow intensity). The correlation coefficient for moderate affected stand by windthrow varies between -0.44 and $-0.54(\mathrm{p}<0.0001)$ (Fig. 1). When analysing the correlation between the basal area increment and the Schütz competition index, the intensity of the correlation is low in the case of the plot that had been highly affected by windfall (43H1 plot) ( $\mathrm{r}=0.13$, $\mathrm{p}=0.18)$ and increases significantly for the plots with low and moderate windthrow intensity ( $\mathrm{r}$ varies between -0.72 and $-0.79, \mathrm{p}<0.0001$ ) (Fig. 2).

The variability of the basal area increment $\left(\ln \Delta g_{10}\right)$ explained by competition indices is rather low $(<2 \%)$ in the stand that had been highly affected by windfall, regardless of the selected competition index (Table 2). The Heigy index accounts between $20 \%$ (moderate wind damage intensity) and 30\% (in stands that were slightly affected by windfall) of variance. However, the Schütz index accounts $63 \%$ of the basal area increment variance for $43 \mathrm{H} 2$ (moderate affected stand) and $52 \%$ for those plot which were low affected by wind damage.

\section{Discussion}

The analysis of the effects of the applied forest management measures is rather difficult in the case of significant wind damages, in terms of their frequency and intensity (Popa 2007). Even site condition and initial stand characteristics for all plots were similar different wind damage intensity were observed.

Wind, as disturbance factor, can affect single tree, group of tress or part of stand (Johnson and Miyanishi, 2007). Depending on the size of gap produced by trees fell the spatial structure changes. When only one tree is felled by wind, changes in competition are low. Increasing of gap size determine a decrease of competition due to high reduction of distance between subject tree and neighbors. Crown parameters are highly influence by local neighborhood competition (Lang et al. 2010). Increase of vegetation space permit trees to invest more resources in extending lateral branches and increase crown area and foliar system.

Crown morphology and area is related with growth rate (Drobyshev et al. 2007). In most cases (except for $43 \mathrm{H} 1$ plot) there was a negative correlation between the level of individual competition and the basal area increment. The correlation is relatively low, but statistically significant in the case of the Hegyi index, based on the ratio between the $\mathrm{DBH}$ weighed by the distance between trees. Other studies reveal this index to be superior because of the correlation between radial increment of the subject tree and it's 
DBH (Holmes and Reed 1991, Garcia-Abril et al. 2007). In some studies for scots pine the Hegyi index explain about $50 \%$ of the variability of a 5 year radial increment (Pukkala and Kolstrom 1987). On the other hand, in the case of natural forests, the Hegyi index accounts for only $32 \%$ of the spruce radial increment variance and $14 \%$ of the silver fir radial increment variance (Duduman et al. 2010). The use of the competition indices in the growth models for scots pine has increased the explained variability by 20\% (Pukkala and Kolstrom 1987).

The growth variability explained by the Schütz index, based on the crown parameters, is double compared to the one accounted for by the Hegyi index. By definition the Schütz index takes into account the lateral shading of the neighbouring trees on the crown of the subject tree (Prevosto 2005). The superiority of the distance related competition indices that take into account the crown parameters has also been noticed in mixed coniferous forests in northern California (Biging and Dobbertin 1995).

In the case of black pine, De Luis et al. (1998) have noticed the fact that the competition level is not influenced by the density of the trees in the stand, as competition indices record competition on an individual level and do not depend on the trees located outside of area of influence.

The incorporation of the competition indices in the individual growth models significantly improves their performance (Biging and Dobbertin 1995, Pretzsch 2009).

The amplitude of both competition index used is low in case of high disturbed stand comparing with low and moderate affected stand. Stand density reduction due to effect of wind damage cause a reduction of competitors and their influence area.

The strong correlation between the basal area increment and the competition indices reveals that the individual growth is highly affected by the spatial location of a tree in the stand, in relation to neighbouring trees (Coutts and Grace 1995). This statement cannot be proved in the case of stands that had been highly affected by windfalls. Thus, a significant reduction of the number of trees in the stand, as a consequence of high intensity windfalls, crown competition has a small influence on the basal area increment. The lack of windfalls or their action with a low intensity could have an effect on normal competition processes which are specific to the structure and functioning of the tree stands and which significantly influence growth. Therefore, the distance between crowns and the relative difference between height of the subject trees and competing trees (elements which have a direct influence on competition between trees in terms of canopy) influence the basal area increment to a greater extent than tree diameter (as an effect of the competition process) or the distance between the trees, in the case of tree stands that are low or moderate affected by windfalls. For studied spruce stands the Schütz index explains the size and intensity of increments better than the Heigy index, based on diameter and distance. In the case of tree stands that had been highly affected by windfall, the competition processes are very low, and both indices equally explain growth variability to a very small extent. Wind damage with high intensity (stand density under 0.3) determines a significant modification of competition and his influence on trees growth.

Further research on the topic will help collect more information on the impact of various disturbances on competition and growth processes manifested both in individual trees and within tree stands.

\section{Acknowledgments}

B.O. and P.I. were supported by Romanian Authority for Research in Core Program for Forestry - GEDEFOR, project PN09460110 and partially by CNCS-UEFISCDI project number PN-IIRU-TE-2011-3-0040. C.C is supported by Phd program of Transilvania University Brasov. Two anonymous reviewers also provided useful comments.

\section{References}

Aakala T., Fraver S., D’Amato A.W., Palik B.J. 2013. Influence of competition and age on tree growth in structurally complex old-growth forests in northern Minnesota, USA. Forest Ecology and Management 308: 128-135.

Biging G.S., Dobbertin M. 1995. Evaluation of competition indexes in individual tree growth models. Forest Science 41: 360-377.

Castagneri D., Vacchiano G., Lingua E., Motta R. 2008. Analysis of intraspecific competition in two subalpine Norway spruce (Picea abies (L.) Karst.) stands in Paneveggio (Trento, Italy). Forest Ecology and Management 255: 651-659.

Contreras M., Affleck D., Chung W. 2011. Evaluating tree competition indices as predictors of basal area increment in western Montana forests. Forest Ecology and Management 262: 1939-1949.

Cook ER., Kairiukstis L.A. 1990. Methods of Dendrochronology: Applications in the Environmental Sciences Kluwer Academic Pub.

Coutts M.P., Grace J. 1995. Wind and trees. Cambridge University Press.

De Luis M., Raventos J., Cortina J., Moro M.J., Bellot J. 1998. Assessing components of a competition index to predict growth in an even-aged Pinus nigra stand. New forests 15: 223-242. 
Drobyshev I., Linderson H., Sonesson K. 2007. Relationship between crown condition and tree diameter growth in southern Swedish oaks. Environmental Monitoring Assessment 128: 61-73.

Duduman G., Roibu C.C., Duduman M.L., Miron-Onciul M. 2010. The influence of competition and dimensional-spatial characteristics of trees on their radial growth in Old-Growth Slătioara forest, Romania. AES Bioflux 2: 215-230.

García-Abril A., Martin-Fernández S., Grande M.A., Manzanera J.A. 2007. Stand structure, competition and growth of Scots pine (Pinus sylvestris L.) in a Mediterranean mountainous environment. Annals of Forest Science 64: 825-830.

Giurgiu V., Decei I., Drăghiciu D. 2004. Methods and dendrometrics tables. Ceres, Bucharest.

Holmes M.J., Reed D.D. 1991. Competition indexes for mixed species northern hardwoods. Forest Science 37: 1338-1349.

Huang J.G., Stadt K.J., Dawson A., Comeau P.G. 2013. Modelling Growth-Competition Relationships in Trembling Aspen and White Spruce Mixed Boreal Forests of Western Canada. PloS one 8: e77607.

Johnson E.A., Miyanishi K. 2010. Plant disturbance ecology: the process and the response. Academic Press.

Lang A.C., Härdtle W., Bruelheide H., Geißler C., Nadrowski K., Schuldt A., Yu M., von Oheimb G. 2010. Tree morphology responds to neighbourhood competition and slope in species-rich forests of subtropical China. Forest Ecology and Management 260: 1708-1715.

Larocque G.R., Luckai N., Adhikary S.N., Groot A., Bell F.W., Sharma M., 2013. Competition theory - science and application in mixed forest stands: review of experimental and modelling methods and suggestions for future research. Environmental Reviews 21: 71-84.
Mailly D., Turbis S., Pothier D. 2003. Predicting basal area increment in a spatially explicit, individual tree model: a test of competition measures with black spruce. Canadian Journal of Forest Research 33: 435-443.

Panayotov M., Kulakowski D., Laranjeiro Dos Santos L., Bebi P. 2011. Wind disturbances shape old Norway spruce- dominated forest in Bulgaria. Forest ecology and Management 262: 470-481.

Popa I. 2007 Managementu riscului la doborâturi produse de vânt. Tehnică Silvică, Bucharest.

Popa I. 2008. Windthrow risk management. Results from Romanian forests. In: Disturbi in foresta ed effetti sullo stock di carbonio: il problema della non permanenzai. Pubblicazione del Corso di Cultura in Ecologia. Atti del $44^{\circ}$ corso. Anfodillo T., Dalla Valle E., Valese E., (eds.). Università di Padova, pp: 77-88.

Pretzsch H., Biber P., Durský J. 2002. The single treebased stand simulator SILVA: construction, application and evaluation. Forest Ecology and Management 162: 3-21.

Prévosto B. 2005. Les indices de compétition en foresterie: exemples d'utilisation, intérêts et limites. Revue Forestière Française 5: 413-430.

Pukkala T., Kolström T. 1987. Competition indices and the prediction of radial growth in Scots pine. Silva Fennica 21: 55-67.

SAS 2013. www.support.sas.com.

Tomé M., Burkhart H.E. 1989. Distance-dependent competition measures for predicting growth of individual trees. Forest Science 35: 816-831.

Ung C.H., Raulier F., Ouellet D., Dhôte J.F. 1997. Lindice de compétition interindividuelle de Schütz. Canadian Journal of Forest Research 27: 521-526. 